\title{
Using Expert System Application to Diagnose Online Game Addiction in Junior High School Students: Case Study in Five Big City in Indonesia
}

\author{
Abd. Aziz ${ }^{1 *}$, Bagus Wahyu Setyawan ${ }^{1}$, Kundharu Saddhono ${ }^{2}$ \\ ${ }^{1}$ Faculty of Education and Teachers' Training, Universitas Islam Negeri Sayyid Ali Rahmatullah Tulungagung, Jl. Mayor \\ Sujadi No.46, Kudusan, Plosokandang, Kec. Kedungwaru, Kabupaten Tulungagung, Jawa Timur 66221, Indonesia \\ ${ }^{2}$ Graduate School of Javanese Language and Literature, Universitas Sebelas Maret, Jl. Ir Sutami No.36 A, Jebres, Surakarta, \\ Kota Surakarta, Jawa Tengah 57126, Indonesia
}

Corresponding Author Email: abd.aziz@iain-tulungagung.ac.id

https://doi.org/10.18280/isi.260503

Received: 20 August 2021

Accepted: 24 September 2021

\section{Keywords:}

expert system application, diagnosis, online game addiction, junior high school students, big city in Indonesia

\begin{abstract}
The development of computer technology gradually increases. An artificial intelligencebased system also begins to be developed and used in various fields. One product of artificial intelligence is an expert system, used for psychological field. This study aimed to explain and describe the using of expert system to diagnose online game addiction to Junior High School Students. This is based on online game addiction phenomenon happening to Indonesian student especially in Junior High School. The implementation of this expert system used certainty factor method. Steps for developing this system were divided into four, namely designing expert system or architecture of expert system, representing knowledge, designing database, and testing and implementing the system. The results indicate that this system is divided into two domains, including user and admin. The user domain is provided for users who are willing to do online consultations using system expert application. Meanwhile, the admin domain is provided for an admin to manage each datum and question from the user who conducts an online consultation. From 1000 samples, it is obtained that $69 \%$ amongst total samples of Junior High School Student have a low-level addiction to online game, $25 \%$ experience medium-level addiction, and $6 \%$ are highly addicted.
\end{abstract}

\section{INTRODUCTION}

The development of today's technology increases fast. Computer-based technology that firstly is used in military and education fields, is now utilized in other crucial fields, such as economy, business, health, food, and so forth [1]. It indicates that human needs practical, effective, and efficient technology to assist each activity. Computer technology simplifies human to do his job without spending too much energy and time since it can be done by computer and robotic systems [2]. The data from Statistics Indonesia (BPS) show that in the last five years, the use of information and communication technology (ICT) by households in Indonesia keeps showing a significant improvement. The percentage of people using cell phones continues to increase and reaches $62.41 \%$ in 2018. The increase of cell phone usage is followed by the increase of computer ownership and internet access in households, indicating $20.05 \%$ for computer ownership and $66.22 \%$ for internet access [3, 4]. The use of internet al.so gradually increases between 2014 and 2018, indicating 17.14\% in 2014 and becoming $39.90 \%$ in 2018 [5].

These data are also supported by Global web index, claiming that Indonesia is in the third rank of population development in accessing internet as much as 17 percent in the last year [6]. This percentage is equal to 25.3 million new internet users in a year. The development of Indonesian population who access internet is under China and India. India becomes the first rank with 127 million new internet users in the last year. In fact, Indonesian people frequently use internet for social media. Besides, the domination of using internet in Indonesia is online game application [7]. It is represented by the data from Global Digital Insight, showing that 20\% internet users between 16 and 64 years old, watch live streams to someone who play a game. Moreover, one of seven people watch e-sport tournament. It shows that games and e-sports become more interesting. In Indonesia, the number of gamers is expected to significantly increase [8]. Pokkt, Decision Lab and Mobile Marketing Association (MMA) studying online game in Indonesia, claimed that the number of mobile gamers in Indonesia reaches 60 million [9]. This number probably increases to 100 million in 2020 . Additionally, a study showed that the major activities conducted by people through smartphone is playing a game or as much as $25 \%$. They usually play mobile games for 53 minutes.

The phenomenon of increasingly playing online games in Indonesia, particularly conducting by adolescences leads to addiction. It is considered as a negative impact of online games. Besides, online games also negatively affect child development, obstruct socialization, implant antipathy toward environment, and negatively affect human emotional $[10,11]$. A survey showed that children are categorized as addicted to online games will do anything to keep connected and able to play online games, even committing criminal actions, such as robbing and extortion [12]. This phenomenon becomes crucial considering dangerous effects on child psychology. Since it does not get solved, it will cause continues indications that will damage child future and Indonesia, in particular. 
As a consequence, this study will develop an expert system able to be used as a tool to detect and diagnose online game addiction to Indonesian adolescence. The expert system is a knowledge-based program providing solutions for problems in a specific domain with the quality of an expert [13]. It is a computer program that imitates thinking process and expert knowledge in solving a certain problem. One of the expert systems developed is Artificial Intelligence (AI) [14]. In its implementation, the expert system with AI is frequently used in psychological field because this system is considered as a way to save expert knowledge of a certain field in a computer program, so the decision can be made in conducting logical reasoning intelligently. The intersection between psychology and expert system creates an area namely cognition and psycholinguistics. In general, its knowledge is taken from a human who is expert in that domain and that expert system attempts to imitate his method and performance [15].

However, the expert system is greatly developed for some fields, beyond psychology. Many studies discuss about expert system, including Qwaider \& Abu Nasser [16] who developed an expert system used for medical technology to diagnose ankle injury. In economy and business, Ong [17] developed an expert system to diagnose the benefit and loss in big companies in Metro Manilla, Philippine. An expert system is also used in the agriculture field as conducted by Zhang, et al. [18] who investigated the use of expert system for managing radish fertilization in China. In education field, an expert system is also used by Hossain et al. [19] to detect student performance in school, and Asabere \& Amoako [20] to improve career decision-making for high school students in Ghana.

As indicated in those studies, the use of expert system is able to make human performance easy and effective, especially in diagnosing a problem [21]. In this study, an expert system implemented is web-based to diagnose online game addiction occurring to Junior High School student. It is crucial and important to conduct this study considering the huge number of online game players in Indonesia in order to anticipate online game addiction in Indonesia, particularly adolescences ages.

\section{METHODS}

This study was developmental research with the employment of R\&D scheme. It aimed to develop an expert system used to diagnose online game addiction to Indonesian adolescences. There were some materials required to be provided in this study, as the followings.

\subsection{Tools and materials}

This study needed a set of computer devices in terms of hardware and software used to develop an expert system. They are the followings.

Hardware is needed to construct a system, such as Processor ASUS A451 LN, CORE i5 RAM 4 GB, HDD 1 TB, Monitor LCD 14 inc, Keyboard, Mouse. Besides, software functions as data processor. It includes Windows 8, Microsoft Word 2007, Microsoft Visio 2010, Apache, PHP, and My SQL database.

\subsection{Subject of research}

In this research subject of research take from some of Junior
High School Student from five Big City in Indonesia, that is Jakarta, Bandung, Surabaya, Makassar, and Medan. Sample of this research took from every Junior High School which have good standard in each city. Data collecting technique using google form which collaborate with National Education Authorities in each country to spread out the google form. Sample of this research is 200 students in each city.

\subsection{Steps}

The first step of this research was to collect the data from psychologists. This data was then summarized to give to online game players from online game providers. This survey was conducted by using google form, filled by students who become gamers in five big cities in Indonesia.

After obtaining the data, the next step was to describe the application being developed. This study conducted the development in terms of application program. It deployed a structured method by creating architecture, knowledge representation, and DFD (Data Flow Diagram). The architecture of this system was designed to describe that this system was able to give consultation facility in diagnosing online game addiction to Junior High School student and getting a solution or doing a prevention to fasten healing process.

Knowledge representation was designed to support logical reasoning in detecting diseases appropriate with the data of symptoms included to the system. After designing the application, the next step was to collect data for designing database. Data inputted to the database include user, addiction, symptom, question, solution, and rule data. These data were then represented in the interrelated table [22]. They are also able to be used as supports, in terms of conclusions, facts, and rules organizing the process of data searching which are interconnected to one another. This is because of that the data inputted by users in this expert system will be included into a database system. The database system was processed by the Entity-Relationship (ER) Model in which each entity is interconnected one another in a system. Hence, designing database was required as a place to save those data. After the data was inputted to the database, the next step was to implement the program. In this step, the system being built was also ready to be operated. The expert system application program in diagnosing online game addiction was used as an interface with users and an inference machine to get a conclusion.

\section{RESULTS AND DISCUSSION}

After conducting the analysis, the study starts to build an expert system which is able to give information and solutions about online game addiction more effectively and efficiently. The steps for developing this system are divided into four, including architecture of the expert system or designing the system, representing the knowledge, designing the database, and testing as well as implementing the system.

\subsection{Building and developing expert system}

Building a software system requires some structured supporting systems. It aims to make software being built able to be well-planed and to have a clear and complete structure. In designing expert system to diagnose online game addiction, 
this study describes the system in terms of:

\subsubsection{Context diagram}

Context diagram is a diagram related to a system beyond the expert system [23]. In addition, the context diagram explains a general image in diagnosing online game addiction through certainty factor method. This diagram and its procedure are reflected as the following Figure 1 .

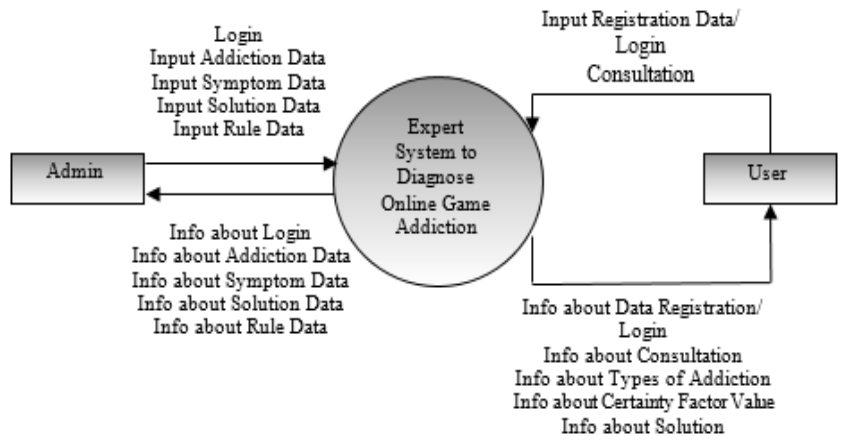

Figure 1. Context diagram in expert system

Figure 1 shows a general image of the expert system in diagnosing online game addiction, relating one part to another. Admin is able to manage the data and process it in the expert system for diagnosing online game addiction in which, later, users are able to interact with the system by doing a consultation so that users get information they need.

\subsubsection{Data Flow Diagram}

Data Flow Diagram (DFD) explains how the system functional process works in detail, relating one part to another. In DFD, there are some steps used to diagnose complaints given by users while consulting to the expert system [24]. The data flow in the DFD system is symbolized by an arrow sign to show the data flow from an entity to others. This data flow shows input for data process or storage and output or the result of a process. In this system, the data flow consists of some process stages including 1) login user, 2) addiction data processing, 3) symptom data processing, 4) question data processing, 5) solution data processing, and 6) rule data processing.

\subsubsection{Entity Relationship Diagram (ERD)}

Entity Relationship Diagram (ERD) is a conceptual model, describing a relationship between storages (in DFD). It is different from DFD (DFD, modelling functions of the system), or STD (state transition diagram, modelling the system based on the dependency of time) $[25,26]$. By ERD, the study is able to test the model by denying the obligatory process. In general, there are some types of the symbol used [27]. The ERD symbol can be seen on this Table 1 .

Table 1. Types ERD Symbol

\begin{tabular}{|c|c|c|c|}
\hline No & Name & $\begin{array}{l}\text { Description } \\
\end{array}$ & Symbol \\
\hline 1 & Entity & $\begin{array}{l}\text { An entity is an object that is able to be identified in users' environment, } \\
\text { an important thing for users in relation to a system made. It is described } \\
\text { as rectangular. }\end{array}$ & \\
\hline 2 & Attribute & $\begin{array}{l}\text { An entity has an element namely attribute, that functions as } \\
\text { explaining characters of an entity. }\end{array}$ & \\
\hline 3 & Relation & $\begin{array}{l}\text { Entities can be related to one another. This relation is called relationship. } \\
\text { A relation between entities must be differentiated between relationship } \\
\text { or relationship form between entities and contents of their relationship. }\end{array}$ & \\
\hline 4 & Link & $\begin{array}{l}\text { Link functions as connecting entities and attributes or entities and } \\
\text { relationships. }\end{array}$ & \\
\hline 5 & Weak Entity & $\begin{array}{c}\text { Weak entity is an entity in which its existent depends on relationship } \\
\text { toward other entities. }\end{array}$ & \\
\hline 6 & Identifying Relationship & $\begin{array}{l}\text { Identifying relationship is a relation connecting a weak entity and an } \\
\text { owner. }\end{array}$ & \\
\hline 7 & Attribute Primary Key & $\begin{array}{l}\text { Attribute Primary Key is an attribute chosen to identify each record } \\
\text { uniquely. It must be an extremely unique field and has no NULL value. }\end{array}$ & \\
\hline 8 & Attribute Multivalue & $\begin{array}{l}\text { Attribute Multivariate is value of an attribute with more than } \\
\text { (multivariate) one values in connection with a related attribute. }\end{array}$ & \\
\hline 9 & Attribute Composite & $\begin{array}{l}\text { Attribute Composite is an attribute that is possibly divided or has sub } \\
\text { attributes. }\end{array}$ & \\
\hline
\end{tabular}

In this ERD, there are some tables consisting of formulas in the expert system to be then used to diagnose online game addiction to Indonesian adolescences. These Tables 2-7 are the followings.
Table 2. Admin table

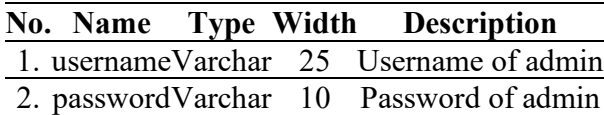


Table 3. Rule table

\begin{tabular}{|c|c|c|c|c|}
\hline No. & Name & Type & Width & Description \\
\hline 1. & id aturan & Int & 5 & Primary key \\
\hline 2. & id_gejala & Varchar & 5 & $\begin{array}{c}\text { Foreign Key from } \\
\text { tb_gejala table }\end{array}$ \\
\hline 3. ic & kecanduan & Int & 5 & $\begin{array}{l}\text { Foreign Key from } \\
\text { tb kecanduan table }\end{array}$ \\
\hline
\end{tabular}

Table 4. Symptom table

\begin{tabular}{ccccc}
\hline No. & Name & Type & Width & Description \\
\hline 1 & id & Int & 11 & Primary key \\
\hline 2 & id_gejala & Varchar & 10 & Not null \\
\hline 3 & nama_gejala & Varchar & 100 & Not null \\
\hline
\end{tabular}

Table 5. Addiction table

\begin{tabular}{lcccc}
\hline No. & Name & \multicolumn{2}{c}{ Type } & WidthDescription \\
\hline 1. & Id kecanduan & Int & 5 & Primary key \\
\hline 2. tingkat_kecanduanVarchar & 50 & Not null \\
\hline
\end{tabular}

Table 6. Question table

\begin{tabular}{|c|c|c|c|c|}
\hline No. & Name & Type & Width & hDescription \\
\hline 1. & Id pertanyaan & Int & 10 & Primary key \\
\hline 2. & nama pertanyaan & IVarchar & 100 & Not null \\
\hline 3. & id gejala & Varchar & & Foreign key \\
\hline 4. & nama_gejala & Varchar & & Foreign key \\
\hline
\end{tabular}

Table 7. Solution table

\begin{tabular}{|c|c|c|c|c|}
\hline No. & Name & Type & \multicolumn{2}{|c|}{ WidthDescription } \\
\hline 1. & Id & Int & 5 & Primary key \\
\hline 2. & at kecar & Varchar & 50 & Not null \\
\hline 3. & Gejala & Text & & Not null \\
\hline 4. & Solusi & text & & Not null \\
\hline
\end{tabular}

\subsection{Design of expert system page for user}

After inputting some formulas from DFD and ERD, the expert system is ready to be used to diagnose online game addiction to Junior High School student. To access this system, a user or someone needs to access a page or an URL given. The access will give to guidance and counseling teacher in each school. The following Figure 2 represents main page after the system is launched.

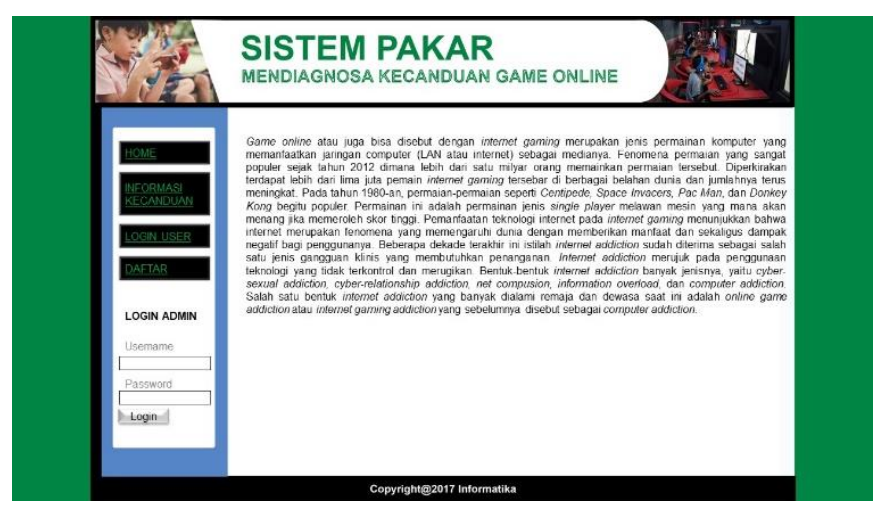

Figure 2. Main page in expert system
The main page is a page containing some links of other pages and relating one page to another. Some menus in the main page include home, addiction information, login user, registration, and login admin.

To be able to do an online consultation with using the expert system, a user needs to do login. If the user has no id, s/he has to do registration by inputting his/her data in the expert system to then get username and password for entering the system. While registering to the system, user needs to fill in some question forms, as follows:

1) Username; it refers to an identification only owned by a user. It is suggested that username of each user is different to avoid errors in reading data.

2) Password; it is a secret word only known by a certain username and used to do login or enter the system. It is personal and only known by the user. It is suggested not to disclose the password to others to minimalize misusing user's data. It consists of a combination of letter or number which is really familiar and easy to be remembered.

3) Sex.

4) Age

5) Birthday.

6) Address.

After filling the registration form, the user is able to enter the system and then do online consultations related to online game addiction. In the consultation page, the user is required to choose symptoms occurring to him/her by giving check marks on symptoms happening to him/herself. It is expected that the user fills the form with full of honesty with respect to what is really happening. The display of consultation menu is represented in the following Figure 3.

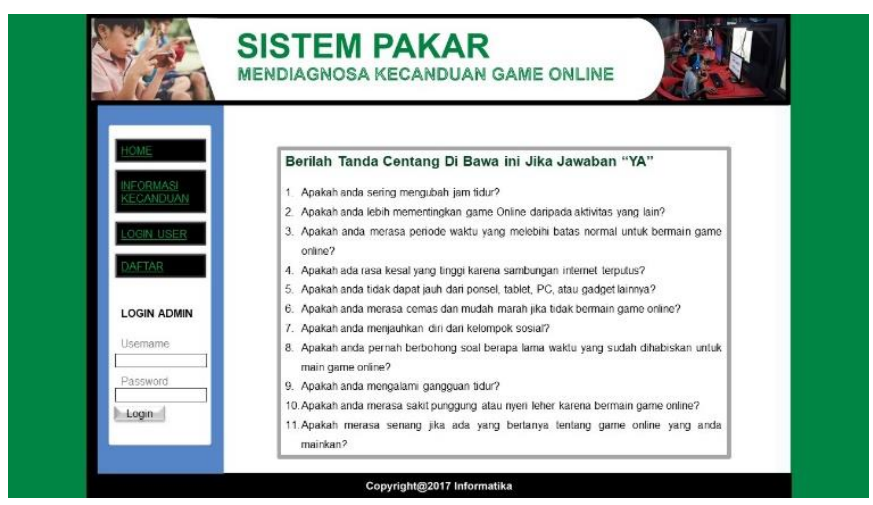

Figure 3. Page of consultation menu

The description of consultation menu list in Figure 3 is shown in the Table 8.

After inputting some symptoms experienced by the user, the system will do diagnosis with reference to the Table of online game addiction included to the system. The diagnosis by the system will be conducted by admin through processing addictions and symptoms data from users. These data are then used to determine solutions or actions needed. After waiting a moment, the diagnosis on symptoms experienced by the user will directly appeared in the diagnosis page. The display of diagnosis result is a conclusion about addiction information based on symptoms chosen by the user in the consultation page. The display of diagnosis result page is shown in the following Figure 4. 
Table 8. Questions list on consultation menu

\begin{tabular}{|c|c|}
\hline No & Questions List \\
\hline 1 & Do you often change time for sleep? \\
\hline 2 & Do you more prioritize online games than other activities? \\
\hline 3 & $\begin{array}{l}\text { Do you feel the period of playing online games exceeds } \\
\text { normal limits? }\end{array}$ \\
\hline 4 & $\begin{array}{l}\text { Do you feel extremely upset because of internet connection } \\
\text { lost? }\end{array}$ \\
\hline 5 & $\begin{array}{l}\text { Could you live without cellphone, tablet, PC or other } \\
\text { gadgets? }\end{array}$ \\
\hline 6 & $\begin{array}{l}\text { Do you feel worried and easily angry if you do not play } \\
\text { online games? }\end{array}$ \\
\hline 7 & Do you separate yourself from social group? \\
\hline 8 & $\begin{array}{l}\text { Have you ever lied about how long time you have spent for } \\
\text { playing online games? }\end{array}$ \\
\hline 9 & Do you experience sleep disorders? \\
\hline 10 & $\begin{array}{l}\text { Do you feel back or neck pain because of playing online } \\
\text { games? }\end{array}$ \\
\hline 11 & $\begin{array}{l}\text { Do you feel happy if someone asks you about online games } \\
\text { you played? }\end{array}$ \\
\hline
\end{tabular}

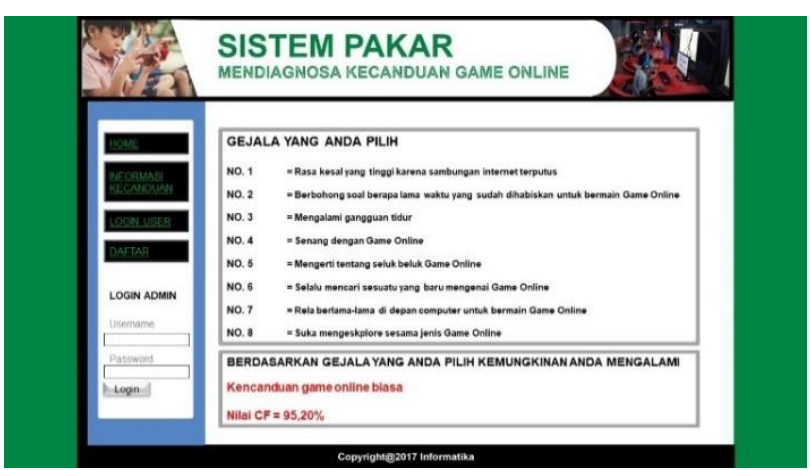

Figure 4. Page of diagnosis result

Figure 4 shows the result of expert system diagnosis on addiction level to online games. They are divided into lowlevel, medium-level, and high-level addictions with reference to symptoms chosen in the consultation page. The percentage of addiction level to online game is also reflected in this page.

\subsection{Design of expert system page for admin}

For admins, the design of expert system used in diagnosing online game addiction is different from the user one. These differences can be seen after the admin or user does login and enters to the system. After the admin does login, the system displays menus related to data from users who do login to do consultation about online game addiction. These data consist of user, addiction, symptom, question, solution, and rule data. The main menu of expert system for admin is represented in the following Figure 5.

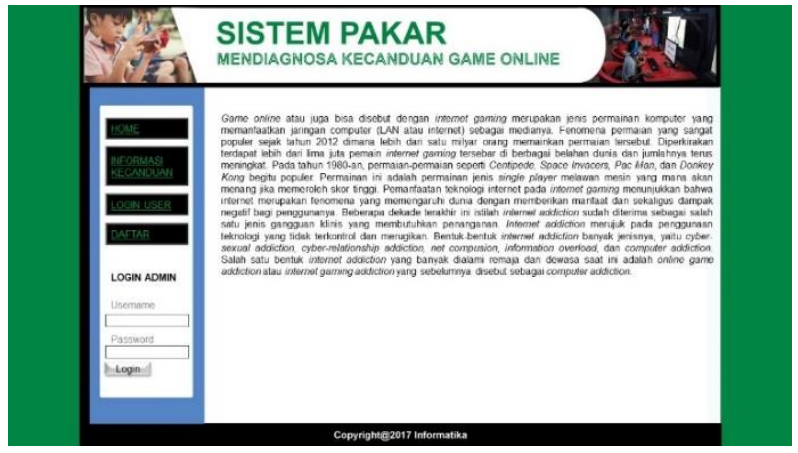

Figure 5. Main Page for guidance and counseling teacher
If admin in this case is guidance and counseling teacher clicks the menu of user data, it will show the data from users or students who do login to the expert system to do consultations. The page of user data is a page where the admin can see which users who finishes their consultations. These data include usernames, passwords, sexes, ages, birthdays, and addresses.

The admin or guidance and counseling teacher can filter and change these data if $\mathrm{s} /$ he finds similar or suspicious data. Validating users' data is carried out by checking the data inputted by users and residence documents for instance Student ID and the data in accordance with National Student ID (NISN). Besides, it also checks suspicious data by directly crosschecking student data in school master books. Thus, the role of admin is to accommodate, control, and recap the data from users who conduct consultation in the expert system.

After that, the addiction data page displays types of addiction to online games. In this page, the admin can add and delete the data. The following Figure 6 shows the page of addiction data in the expert system managed by the admin.

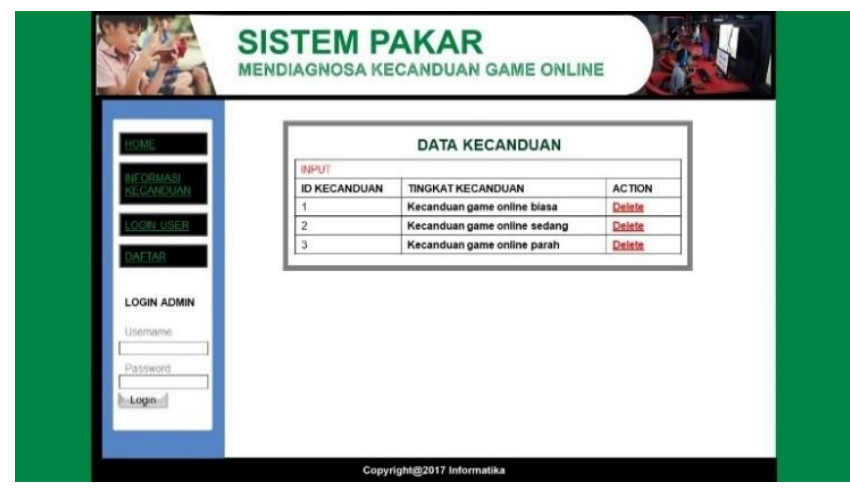

Figure 6. Page of Students Addiction Data

A menu of symptom data is used to show addiction symptom data to online games. The function of admin is still the same, in terms of managing symptoms in the addiction table. The admin is also able to change the data by adding or reducing them.

The next menu for admin is question data page. This page is used to show the data about questions for users/students while online consultation in the expert system. The admin is able to manage these data. The admin is also able to add and reduce questions in diagnosing level of user addiction to online games. The page of question data is the following (Figure 7).

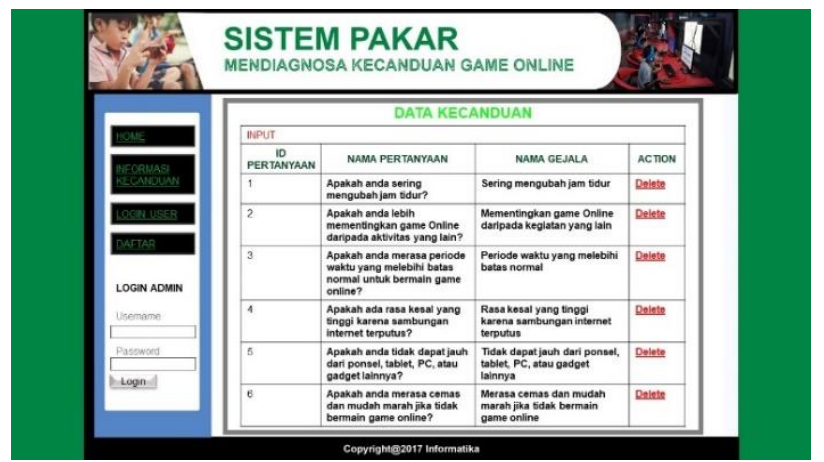

Figure 7. Page of question data from students

The page of solution data is a page used to process the data about questions and consultations from users. These data are then adjusted to the formula of solution Table from symptoms 
and questions answered by users. After that, the admin is able to process it by giving addition or reduction on a solution created by the expert system. In this step, admin's competency is tested. If someone becomes an admin in this expert system, s/he firstly needs to know about online game addiction, its symptoms, and solutions. Furthermore, it is better to put people who are competent in counseling or a psychologist as admin. The following Figure 8 displays the data solution managed by the admin.

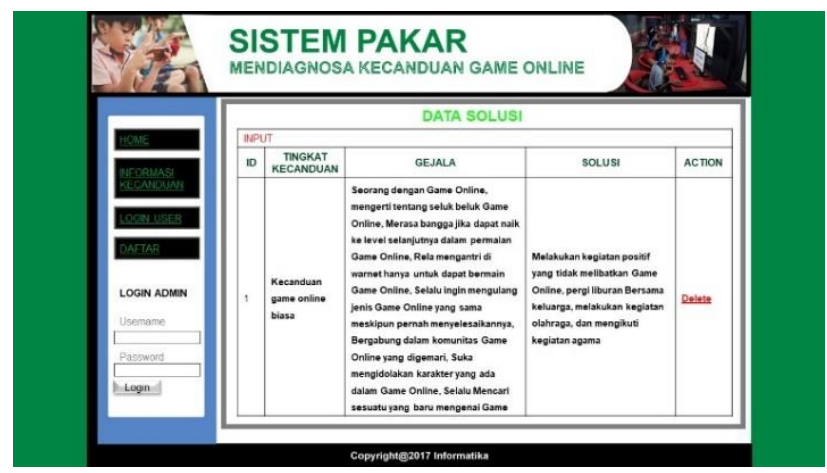

Figure 8. Page of Solution data for students

The page of rule data contains formulas or probabilities used to diagnose the addiction level to users. The data in this rule Table are obtained from the Table of online game addiction symptoms that have been interrelated, and its density value of each symptom. They are then used to determine whether a user is categorized into low, medium, or high-level addictions. Besides, they also function to give the percentage of users' addiction level to online games.

After obtaining the data from users who are completed online consultations, the study conducts the data recapitulation. 1000 samples of online game users selected from some Junior High School Students in Five Big City in Indonesia who finish answering 11 questions. The study reflects $69 \%$ amongst the total Junior High School Students experience the low-level addiction to online game, $25 \%$ have medium-level addiction, and $6 \%$ show high-level addiction to online games. It is represented in the following table.

Table 9. Addiction level of users

\begin{tabular}{cccc}
\hline No. & Types of Addiction & Frequency & Percentage \\
\hline 1. & $\begin{array}{c}\text { Low Level Addiction to } \\
\text { Online Games }\end{array}$ & 690 & $69 \%$ \\
\hline 2. & $\begin{array}{c}\text { Medium Level Addiction to } \\
\text { Online Games }\end{array}$ & 250 & $25 \%$ \\
\hline 3. & $\begin{array}{c}\text { High Level Addiction to } \\
\text { Online Games }\end{array}$ & 60 & $6 \%$ \\
\hline
\end{tabular}

Table 9 shows that the dominant online game players are male students indicating that about $80 \%$ male students are online game players. It is suggested that the level of female students' interest on online games is low. Moreover, the age range of online game players is variative, but it ranges between Senior High School ages, 12 and 15 years olds. This represents that the distribution of online game players mostly spreads all ages.

\section{CONCLUSION}

As discussed above, it is concluded that the development of expert system becomes important to diagnose online game addiction to Junior High School Students, considering the huge number of online game users. It is developed into webbased with the employment of certainty factor method. This expert system consists of two domains, in terms of user and admin. The result of testing users, many users did consultations through the expert system web and got diagnosis. It showed that this expert system is beneficial and able to be used by users or Junior High School Students with online game addiction. Additionally, the admin in this case is guidance and counseling teacher also able to accommodate questions and symptoms from users to be then able to give a diagnosis and treatment to users or their students. Based on the result of testing Junior High School Students, the tendency of Junior High School Students shows a low-level addiction as much as $69 \%$, medium-level addiction as much as $25 \%$, and high-level addiction as much as $6 \%$. However, user and admin domains should have differences despite their similar appearances. Henceforth, this expert system requires improvement to optimize its functions.

\section{REFERENCES}

[1] Malen, J., Marcus, A.A. (2017). Promoting clean energy technology entrepreneurship: The role of external context. Energy Policy, 102: 7-15. https://doi.org/10.1016/j.enpol.2016.11.045

[2] Sudarsana, I.K., Putra, I.P.A.W., Anam, F., Istianti, T., Pandin, M.G.R., Bhawika, G.W., Listiawan, T., Saddhono, K., Abdullah, D., Cathrin, S., Hadjri, M.I., Laili, N.R. (2019). The function of technology and device laptop for education purpose. In Journal of Physics: Conference Series, 1363(1): 12062. https://doi.org/10.1088/1742-6596/1363/1/012062

[3] Fitri, F.S., Si, M.N.S., Setianingsih, C. (2018). Sentiment analysis on the level of customer satisfaction to data cellular services using the naive bayes classifier algorithm. in 2018 IEEE International Conference on Internet of Things and Intelligence System (IOTAIS), pp. 201-206. https://doi.org/10.1109/iotais.2018.8600870

[4] Saddhono, K., Hasibuan, A., Bakhtiar, M.I. (2019). Facebook as a learning media in TISOL (Teaching Indonesian to speakers of other languages) learning to support the independency of foreign students in Indonesia. In Journal of Physics: Conference Series, 1254(1): $12061 . \quad$ https://doi.org/10.1088/17426596/1254/1/012061

[5] Zhou, T. (2015). An empirical examination of users' switch from online payment to mobile payment. International Journal of Technology and Human Interaction (IJTHI), $11(1)$. https://doi.org/10.4018/ijthi.2015010104

[6] Komala, L., Komariah, K., Novianti, E., Subekti, P., Lukman, V. (2019). Utilizing social media for socialization of gema cermat program by public health office of west java indonesia. In Journal of Physics: Conference $\quad$ Series, $1175(1)$ : 12233. https://doi.org/10.1088/1742-6596/1175/1/012233

[7] Carras, M.C., Van Rooij, A.J., Van de Mheen, D., Musci, R., Xue, Q.L., Mendelson, T. (2017). Video gaming in a hyperconnected world: A cross-sectional study of heavy gaming, problematic gaming symptoms, and online socializing in adolescents. Comput. Human Behav., 68: 
472-479. https://doi.org/10.1016/j.chb.2016.11.060

[8] Juliantari, N.K., Sudarsana, I.K., Sutriyanti, N.K., Astawa, I.N.T., Putri, I.D.A.H., Saddhono, K. (2018). Educational games based in information technology as innovation evaluation activity in learning. in Journal of Physics: Conference Series, 1114(1): 12041. https://doi.org/10.1088/1742-6596/1114/1/012041

[9] Mun, I.B., Lee, S. (2021). The influence of parents' depression on children's online gaming addiction: testing the mediating effects of intrusive parenting and social motivation on children's online gaming behavior. Current Psychology, pp. 1-10 https://doi.org/10.1007/s12144-021-01854-w

[10] Xu, X., Yang, X.D., Lu, J., Lan, J., Peng, T.Q., Wu, Y., Chen, W. (2017). Examining the effects of network externalities, density, and closure on in-game currency price in online games. Internet Res. https://doi.org/10.1108/intr-07-2016-0201

[11] Snodgrass, J.G., Dengah II, H.J.F., Lacy, M.G., Bagwell, A., Van Oostenburg, M., Lende, D. (2017). Online gaming involvement and its positive and negative consequences: A cognitive anthropological 'cultural consensus' approach to psychiatric measurement and assessment. Comput. Human Behav., 66: 291-302. https://doi.org/10.1016/j.chb.2016.09.025

[12] Saddhono, K., Setyawan, B.W., Raharjo, Y.M., Devilito, R. (2020). The diagnosis of online game addiction on Indonesian adolescent using certainty factor method. Ingénierie des Systèmes d'Information, 25(2): 191-197. https://doi.org/10.18280/isi.250206

[13] Mattar, J., Goi, V.M. (2019). Digital games for diagnostic assessment of cognitive skills and competences: Literature review and framework. in Handbook of Research on Immersive Digital Games in Educational Environments, IGI Global, 2019, pp. 260286. https://doi.org/10.4018/978-1-5225-5790-6.ch010

[14] Prasetyadi, G.C., Mahfudin, M. (2017). Web-based expert system application to recommend computer specifications for gaming using backward chaining inference method. J. Sist. Inf., 13(2): 110-117. https://doi.org/10.21609/jsi.v13i2.546

[15] Kusumadewi, S. (2003). Artificial intelligence (teknik dan aplikasinya). Yogyakarta Graha Ilmu, vol. 278.

[16] Mahmoud, A., Abo Naser, A., Abu-Amara, M., Sheltami, T., Nasser, N. (2018). Software-defined networking approach for enhanced evolved packet core network. International Journal of Communication Systems, 31(1): e3379. https://doi.org/10.1002/dac.3379

[17] Walek, B., Fojtik, V. (2020). A hybrid recommender system for recommending relevant movies using an expert system. Expert Systems with Applications, 158: 113452. https://doi.org/10.1016/j.eswa.2020.113452

[18] Zhang, J., Ding, W., He, P., Xu, X.P., Abbas, T., Ullah, U.S., Ai, C., Li, M.Y., Cui, R.Z., Jin, C.W., Zhou, W. (2019). Establishment and validation of nutrient expert system for radish fertilization management in China. Agron. J., 111(5): 2435-2444. https://doi.org/10.2134/agronj2019.01.0005

[19] Hossain, S., Sarma, D., Tuj-Johora, F., Bushra, J., Sen, S., Taher, M. (2019). A belief rule based expert system to predict student performance under uncertainty. 2019 22nd International Conference on Computer and
Information Technology (ICCIT), pp. 1-6. https://doi.org/10.1109/ICCIT48885.2019.9038564

[20] Asabere, N.Y., Amoako, E. (2020). Improving career decision-making for high school students through a webbased expert system: Field testing in ghana. Int. J. ICT Res. Africa Middle East, 9(1): 1-23. https://doi.org/10.4018/978-1-7998-8963-2.ch016

[21] Abdullah, D., Pardede, A.M.H., Umami, L., Manurung, R.T., Suryani, R., Surya, S., Saddhono, K., Mulyaningsih, I., Sudarsana, I.K., Brata, D. (2019). Drug users prediction using backpropagation educationalmethod. In Journal of Physics: Conference Series, 1361(1): 12055. https://doi.org/10.1088/1742-6596/1361/1/012055

[22] Liang, C., Wang, S., Chen, R., Zhao, S., Wu, Y. (2020). Research on ship electronic power system fault diagnosis based on expert system. in IOP Conference Series: Materials Science and Engineering, 738(1): 12017. https://doi.org/10.1088/1757-899X/738/1/012017

[23] Wang, C., Wu, F. (2018). An expert system approach to support blended learning in context-aware environment. in Lecture Notes in Computer Science, pp. 45-56. https://doi.org/10.1007/978-3-319-94505-7_3

[24] Zhang, H., Liu, W., Xiong, H., Dong, X. (2018). Analyzing data flow diagrams by combination of formal methods and visualization techniques. J. Vis. Lang. Comput., 48: 41-51. https://doi.org/10.1016/j.jvlc.2018.08.001

[25] Yang, L., Cao, L. (2017). A study on the effect of visualization in teaching entity-relationship diagram (Erd) to relational schema mapping. Edulearn17 Proceedings, 2017. https://doi.org/10.21125/edulearn.2017.0276

[26] Saad, N.A.M., Muniandi, M. (2020). The reflections on the using of oracle data modeler in creating entity relationship diagram (ERD). International Journal of Research Publications, 66(1): 7. https://doi.org/10.47119/ijrp1006611220201601

[27] Sutabri, T. (2012). Analisis Sistem Informasi. Andi Offset, Yogyakarta.

\section{APPENDIX}

\section{Attachment 1. Google Form for Respondent}

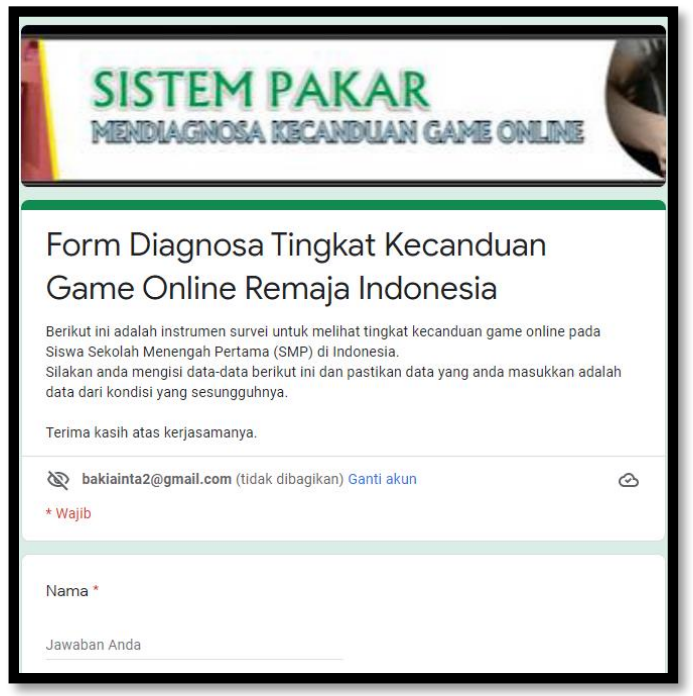



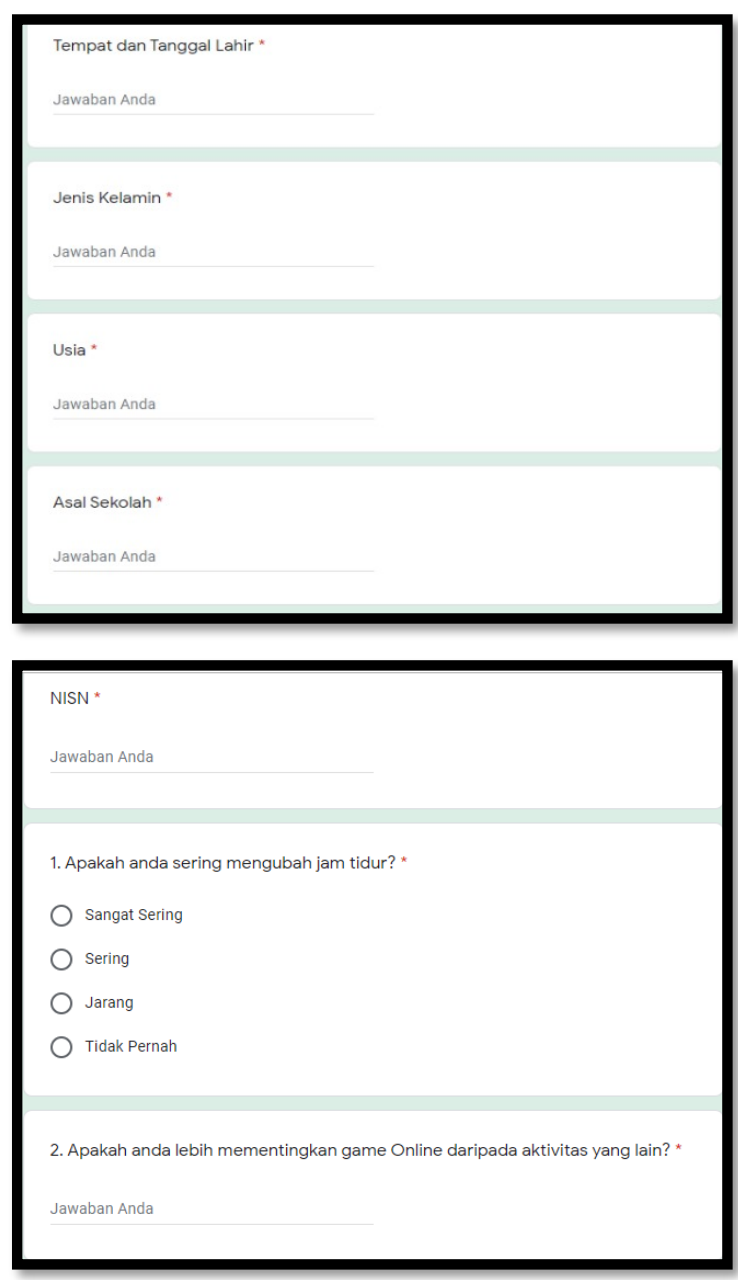

3. Apakah anda merasa periode waktu yang melebihi batas normal untuk bermain
game online?*
O sangat Sering
O sering
Jarang
O Tidak Pernah
4. Apakah ada rasa kesal yang tinggi karena sambungan internet terputus? *
O sangat kesal
O Kesal
O Biasa
O Tidak Kesal

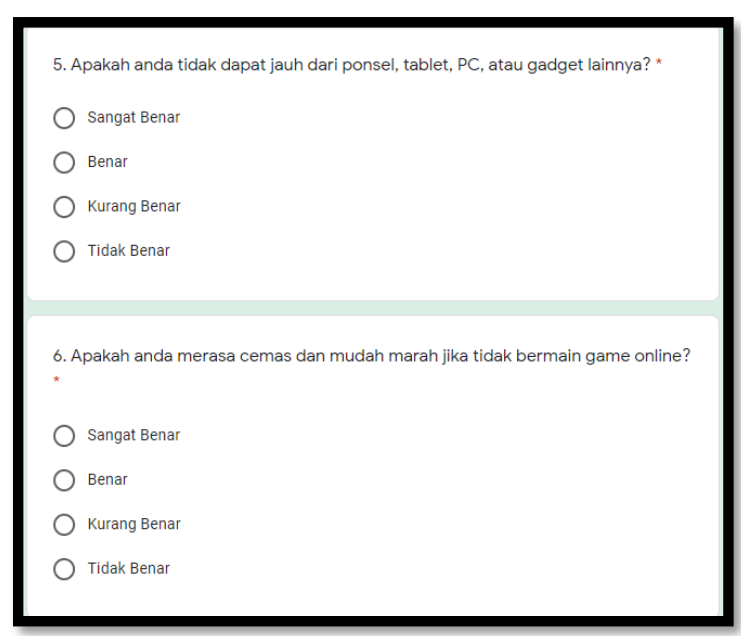

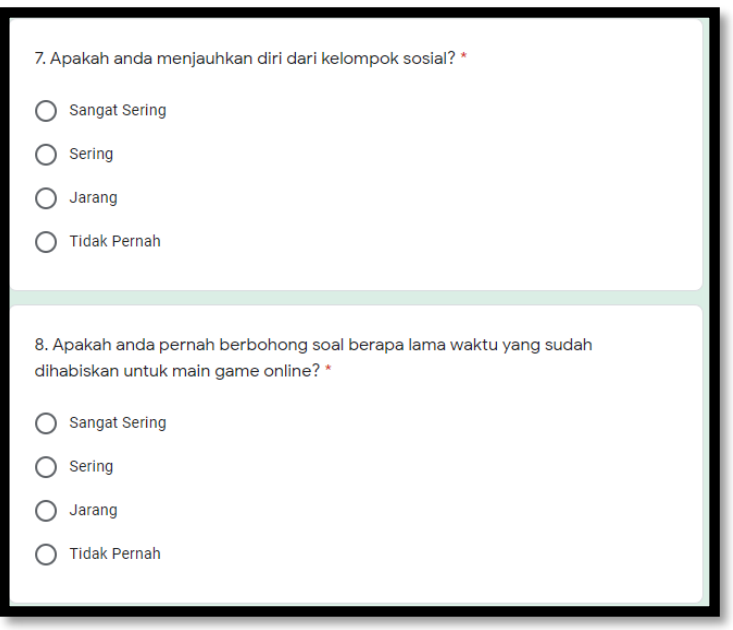
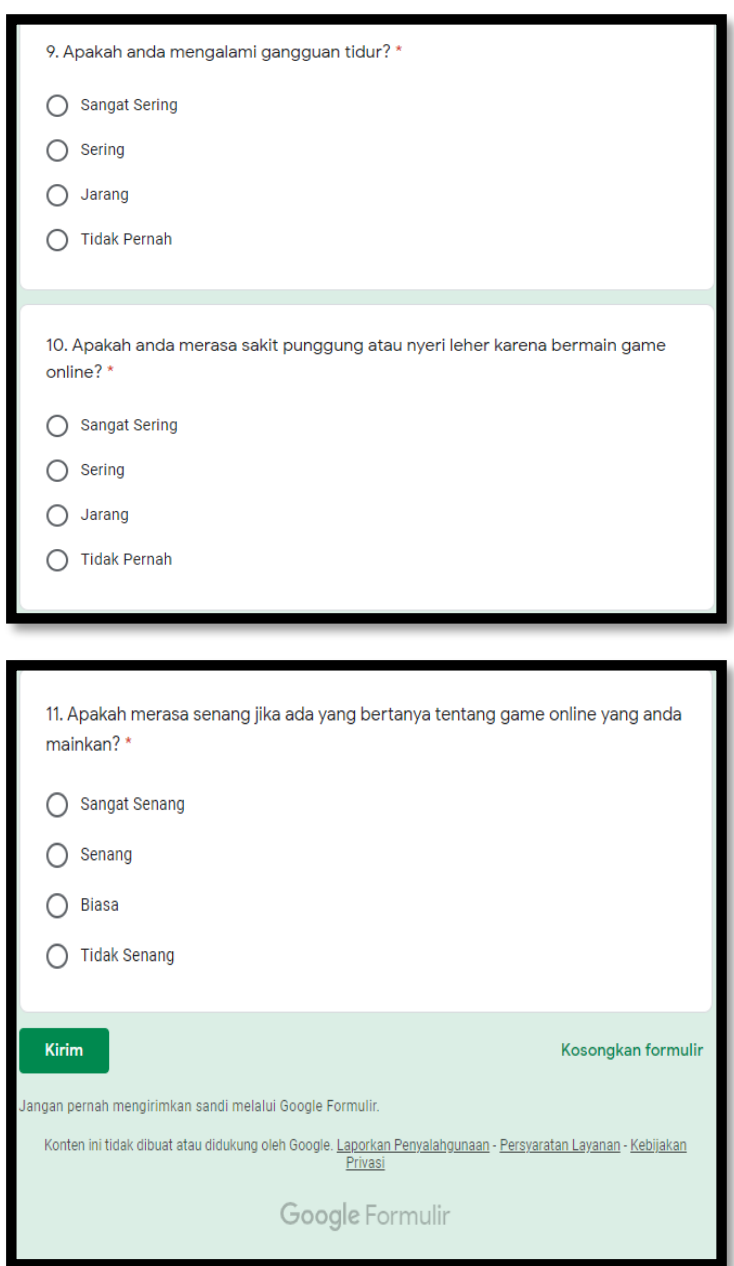